Pamiętnik Literacki 2019, 4, s. 209-223

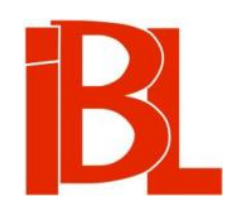

\title{
W drodze do "magnetycznego punktu". Poetyckie dialogi Ryszarda Krynickiego z Paulem Celanem i Nelly Sachs
}

Agata Stankowska 
Pamiętnik Literacki CX, 2019, z. 4, PL ISSN 0031-0514

DOI: $10.18318 / \mathrm{pl} .2019 .4 .15$

AGATA STANKOWSKA Uniwersytet im. Adama Mickiewicza, Poznań

\section{W DRODZE DO „MAGNETYCZNEGO PUNKTU” POETYCKIE DIALOGI RYSZARDA KRYNICKIEGO Z PAULEM CELANEM I NELLY SACHS}

Dykcja poetycka Ryszarda Krynickiego ulegała wielokrotnie zasadniczym zmianom, symetrycznym wobec zwrotów, jakich autor Przekreślonego początku dokonywał w przestrzeni namysłu poetologicznego. Różnie formułowany cel tworzenia, najpierw przez zafascynowanego Tadeuszem Peiperem debiutanta, później zaangażowanego w sprawy społeczne przedstawiciela Nowej Fali, a wreszcie - przez skupionego na metafizycznych zadaniach liryki twórcę pytającego o tajemnicę istnienia, wymuszał każdorazowo zmiane języka. Idiom Krynickiego ewoluował: „Od "seksualnych wulgaryzmów" do "poezji jak hinduska świątynia", "jakby japońskiego haiku pisanego na murach Granady". Od "poetyki negatywnej" do milczenia, "od skrajnego nadmiaru do skrajnej ascezy", do "ulotek wyrytych w kamieniu", wierszy-napisów "na fajansowym naczyniu "' ${ }^{1}$. Te zebrane przez Dariusza Pawelca, inkrustowane frazami zaczerpniętymi z liryki Krynickiego, skrzydlate słowa krytyki towarzyszącej kolejnym tomom poety mówią same za siebie. Na przemianę jako na stałą dyspozycję twórczości autora Niepodległych nicości zwracali zgodnie uwagę wszyscy, którzy o artyście pisali: Jerzy Kwiatkowski, Marian Stala, Alina Świeściak, Tadeusz Nyczek, by wymienić najistotniejszych komentatorów. Zgodni oni byli także co do zasadniczego kierunku ewolucji, właściwej - dodajmy - większości przedstawicieli tzw. pokolenia '68. U swych początków, kwestionując znaczenie tradycji symbolistycznej, nowofalowcy skupiali się na komunikacyjno-społecznych walorach języka poetyckiego. Interwencyjne próby zobrazowania szarej prawdy życia w PRL-u, lingwistyczne starcia $z$ nowomowa, pozwalające odebrać zideologizowanemu językowi jego samowystarczalność, gry etyczne $z$ cenzura, dezaprobata dla strategii pielęgnowania rezerwatów poetyckich, służyły w młodzieńczych wierszach tych autorów mierzeniu się zaangażowanej liryki ze społeczno-polityczną współczesnością. Zarówno Stanisław Barańczak, Adam Zagajewski, jak i interesujący mnie tutaj Krynicki po latach doświadczyli podobnej tęsknoty za metafizycznym wymiarem rzeczywistości, pomijanym bądź tonowanym w ich wczesnej liryce ${ }^{2}$. Wielką rolę

1 D. P a w e le c, Ryszard Krynicki. Hasło w: Polska poezja współczesna. Przewodnik encyklopedyczny. Na stronie: http:// przewodnik poetycki.amu.edu.pl/encyklopedia/ryszard-krynicki (data dostępu: 31 X 2017).

2 P. B o gal e c ki (Szczęśliwe winy teolingwizmu. Polska poezja po roku $1968 \mathrm{w}$ perspektywie postsekularnej. Kraków 2016, s. 33), pytając o rozwój poetyk lingwistycznych po roku 1968 i ich związek z problematyką teologiczną, co pozwala mu wyodrębnić tzw. nurt teolingwizmu, przedsta- 
w tworzeniu nowego idiomu poetyckiego, stosownego wobec tych odpoznanych zainteresowań, odegrała lektura liryki europejskiej: metafizycznych poetów angielskich - w przypadku Barańczaka, liryki niemieckojęzycznej, jeśli chodzi o Krynickiego.

Nie może być tu, rzecz jasna, mowy o wpływie rozumianym jako prosta symetria form i tematów, o przejmowaniu, różnych przecież, cech poetyki: Friedricha Hölderlina, Georga Trakla, Reinera Kunzego, Yvana Golla, Gottfrieda Benna, Hansa Magnusa Enzensbergera, Paula Celana czy Nelly Sachs, których polski poeta tłumaczył. (Dwojgu ostatnim poświęcił - jak wiadomo - najwięcej uwagi, przygotowując, należące do najlepszych w języku polskim, obszerne tomy przekładów twórczości autorów Przełomu oddechu 〈Atemwende, 1967〉 i Rozżarzonych zagadek 〈Glühende Rätsel, 1964〉.) Mowa być może jedynie (a może aż!) o zbliżaniu się Krynickiego do budowanej - przez lirykę tych wielkich niemieckojęzycznych poetów sfery światoodczucia, której bieguny (zaryzykuję tu uproszczenie $z$ pełną świadomością, że jest właśnie uproszczeniem) wyznaczają pospołu: tradycja symbolistyczna ${ }^{3}$, doświadczenie traumy, w którego obliczu dążność do precyzji owocuje często formą eliptyczną, operująca różnymi odmianami milczenia, i wreszcie, swoiste metafizyczne wychylenie, rodzace się - dodajmy - „w cieniu nihilizmu” ${ }^{4}$, jak trafnie zauważył Hans-Georg Gadamer w szkicu poświęconym głównie Celanowi.

Krynicki nadmienia, że jego pierwsze próby przekładowe są równoległe wobec twórczości oryginalnej; pochodza jeszcze z 1968 roku$^{5}$. Poeta znał wówczas jedynie język rosyjski i trochę łacinę. „Prawdziwe tłumaczenie zacząłem znacznie później” ${ }^{-}$

wia Krynickiego jako poetę, który - inaczej niż Wirpsza czy Karpowicz - przeżywa wyraźny „zwrot ku problematyce metafizycznej, przy dostrzegalnym "ukonkretnieniu" i "rozproszeniu" poetyki lingwistycznej”. Badacz bardziej skłonny jest zatem łączyć dojrzałą twórczość Krynickiego z powrotem do tradycyjnych form poezji mistycznej kontynuującej metafizyczny namysł nad Słowem, niż przypisywać tę twórczość do późnonowoczesnych poszukiwań nowych form duchowości, które $z$ ironicznym dystansem służą formułowaniu pytań o „immanentne językowe ramy [...] duchowych poszukiwań" (ibidem, s. 40), a także o religię i o złożoność relacji, jakie homo religiosus zawiązuje między sobą a światem.

3 Postawienie takiej tezy wymaga dopowiedzenia, z jakim nurtem, z jakim sposobem rozumienia symbolizmu należy Krynickiego łączyć. Na jego twórczość, lecz też na wypowiedzi programowe, można niewątpliwie patrzeć przez pryzmat dyskusji, jaka toczyła się w Polsce na początku lat siedemdziesiątych wokół dwóch stron symbolizmu - akcentującego bądź transcendencję słowa rozumianego jeszcze jako logos, bądź też autonomiczny, arbitralny znak, unieważniający mityczne źródło poezji. W wymianie zdań uczestniczyli nie tylko nowofalowcy, ale również krytycy i inni poeci, tacy jak Z. Bieńkowski oraz Z. Herbert. Wątki dotyczące różnych sposobów rozumienia symbolizmu (i postrzeganego w jego kontekście lingwizmu) zebrali w najnowszych pracach A. Klu ba (Autoteliczność, referencyjność, niewyrażalność. O nowoczesnej poezji polskiej 〈19181939). Wrocław 2004, s. 17-60) i T. Ci e śla k-S o k oł ow s ki (Moment lingwistyczny. O wczesnym pisarstwie Ryszarda Krynickiego i Stanisława Barańczaka. Kraków 2011, s. 96-100, 132-179). Ten ostatni, co ważne, w bezpośrednim odniesieniu także do programu poetyckiego wczesnego Krynickiego.

4 H.-G. Gad a mer, W cieniu nihilizmu. W: Poetica. Wybrane eseje. Przel. M. Łuk a siewicz. Warszawa 2001.

5 Zob. D. S u s ka, Uczmy się czytać bezinteresownie. W zb.: Gdybym wiedziat. Rozmowy z Ryszardem Krynickim. Oprac. A. Krzy w a nia. Wrocław 2014, s. 66. (Pierwodruk: „Życie” 1997, nr 63). 
wspomina - kiedy to, nauczywszy się języka niemieckiego, by móc czytać Rilkego $\mathrm{w}$ oryginale, sięgnał po wiersze Celana i Sachs ${ }^{7}$.

Autorowi Aktu urodzenia nie chodziło jedynie o przybliżenie polskim czytelnikom wybranych tekstów poetów niemieckojęzycznych. Raczej o odkrycie i wskazanie tradycji ważnej dla jego własnych poszukiwań. Warto przypomnieć, że Krynicki szybko odnajduje w translacji podstawową formułę bycia w literaturze i w kulturze w ogóle. Rozumie ją jako rodzaj uczestnictwa w dialogu, którego przedmiotem jest namysł nad problemami, jakie za Henrykiem Elzenbergiem mógłby nazwać „kłopotami $z$ istnieniem" ${ }^{8}$. Dialogu, w który on sam jako twórca wiązanego słowa włącza się nie tylko pisząc wiersze własne, lecz z premedytacją „przemawiają" w polszczyźnie głosem poetów, którzy bliskie mu wątki sformułowali wcześniej, wyraziwszy je (co lubi podkreślać) w sposób nie tylko mu bliski, ale i niedościgniony. W jednym $\mathrm{Z}$ wywiadów Krynicki wyznawał:

mnie się wydaje, że w ogóle literatura jest przekładem czy tłumaczeniem i że nasz własny wiersz jest również (mniej lub bardziej wiernym) przekładem jakiegoś głębokiego przeżycia, jakiegoś istotnego doświadczenia, jakiegoś duchowego odkrycia, które domaga się wyrażenia ${ }^{9}$.

Innym razem wyjaśniał poeta sens własnych translatorskich prób:

Lubię tłumaczyć cudze wiersze, bo mam poczucie, że robię wtedy coś pożytecznego. [...] Łatwiej [jest mówić o sprawach fundamentalnych głosem innych poetów - A. S.] ${ }^{10}$, poza tym oni powiedzieli to już znacznie wcześniej, lepiej więc ich przekładać, niż po nich powtarzać ${ }^{11}$.

Nietrudno zauważyć, iż tak rozumiana działalność translatorska nabiera w pewnej mierze cech twórczości prymarnej. Przyznane jej zostaje bowiem miejsce „nie obok”, ale „wewnątrz” własnego głosu poety ${ }^{12}$. Podobnie zreszta jak przekład sensu stricto okazuje się jedną $\mathrm{z}$ form translacji sensu largo.

$7 \quad$ Krynicki nadmienia w jednym $z$ wywiadów, że $z$ wierszami N. Sachs zetkną się po raz pierwszy w przekładach Herberta. Wcześniej czytał Fugę śmierci i kilka innych wierszy P. Celana w tłumaczeniach S. J. Leca i S. Barańczaka. Zob. P. Kę p ińs ki, Poezja nie ocali świata. W zb.: Gdybym wiedziat, s. 41. (Pierwodruk: „Plus Minus”. Dodatek do „Rzeczpospolitej” 1995, nr 151).

8 H. Elzen ber g, Kłopot z istnieniem. Aforyzmy w porząku czasu. Kraków 1994.

9 B. Maj, M. Stala, Literatura jest tłumaczeniem. W zb.: Gdybym wiedziat, s. 38. (Pierwodruk: „NaGłos” 1993, nr 11).

10 Krynicki odpowiada tu twierdząco na pytanie sformułowane przez K. J a n ow s ką i P. M u c hars ki e g o (O milczeniu. W zb.: Gdybym wiedziat, s. 103. 〈Pierwodruk: K. J a now ska, P. Much a r s ki, Rozmowy na nowy wiek. T. 1. Kraków 2001)).

Ibidem.

12 Krynicki zwykł stopniować poziom zbliżenia się do oryginału. W jednym z wywiadów mówił: „Odróżniam nieprzetłumaczalne od nieprzekładalnego. W wielkim uproszczeniu: słowa "przekład" używam wtedy, gdy mam poczucie, że lepiej nie mogłem tego po polsku powiedzieć i że zachowałem w miarę wiernie właściwości oryginału. Słowem "tłumaczenie" natomiast posługuję się wtedy, kiedy wiem, że mój tekst od oryginału odbiega i, moim zdaniem, nie da się tego uniknąć” (A. B e rn at, Wiersz jest dziełem otwartym. W zb.: Gdybym wiedziat, s. 76. 〈Pierwodruk: „Nowe Książki” 1997, nr 63〉).

Rozróżnienie to E. Raj ews ki ej (Ocierajace się o siebie metafizyki. Krynicki, Celan, Sachs, Enzensberger. W zb.: Słowa? Tchnienia? O poezji Ryszarda Krynickiego. Wstęp P. Śli w iń s ki. Poznań 2009, s. 112) pozwoliło postawić tezę, iż w koncepcji translatorskiej Krynickiego „tłumaczenie jest czymś bardziej własnym niż przekład”. 
Określony obszar XX-wiecznej tradycji niemieckojęzycznej, liryki kontynuującej - jeśli można tak rzec - linię Rilkego i Hölderlina, Krynicki odkrywa jako niezwykle bogaty rezerwuar bliskich mu, a nie wyrażonych wcześniej w polszczyźnie translacji doświadczenia człowieka XX stulecia, pogrążonego w strasznej historii, ale też szukającego jakichś uniwersalnych dróg wyjścia z traumy czy choćby z poczucia pustki. W utworach Celana i Sachs, Trakla i Kunzego polski poeta odnajduje zbiór zapisów odkryć duchowych wyrastających tyleż z dramatycznych historii, co z odwiecznych metafizycznych pytań, których wagę sam - przynajmniej od początku lat osiemdziesiątych ${ }^{13}$ - podnosić zaczyna $\mathrm{z}$ nieporównywalnie większą siłą, niż czynił to w czasach nowofalowego zaangażowania we „współczesność” ${ }^{14}$, a także w trudnych miesiącach stanu wojennego, kiedy przemawiał (co słusznie zarzucali mu krytycy) głosem zaangażowanym i uproszczonym.

Posługiwanie się przekładem jako formą wypowiedzi własnej pozwala Krynickiemu nie tylko uniknąć powtarzania tez już wcześniej postawionych. Pozwala na coś o wiele donioślejszego. Jest $\mathrm{w}$ gruncie rzeczy tożsame ze zgłoszeniem akcesu do tradycji nie tylko starszej niż rodzima (uprzedniej wobec śladów dążeń pokrewnych i doświadczeń zapisanych w języku polskim), ale też - co wydaje się szczególnie ważne - umożliwiającej spojrzenie w perspektywie uniwersalizującej na swoje przeszłe próby poetyckie, wobec których autor Magnetycznego punktu przyjmuje z czasem postawę wyraźnie zdystansowaną i krytyczną.

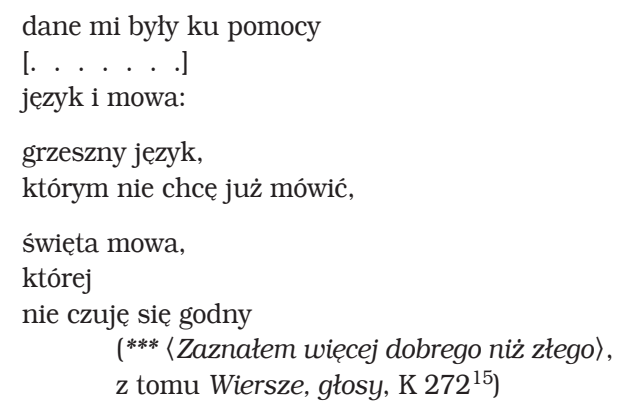

- notuje Krynicki w wierszu napisanym w 1987 roku. Waga tradycji symbolistycznej wydaje się $\mathrm{w}$ tej optyce nie do przecenienia, a wybierana liryka niemieckojęzyczna jawi się polskiemu poecie jako arcydzielny wzór tak rozumianej „świętej mowy". To nie przypadek, że Krynicki - pytany o sens tłumaczenia Celana - podkreślać będzie bliskość autora Zagrody czasu (Zeitgehöft, 1976) z mistyką otwiera-

Sam Krynicki powie, że zmiana ta zaczyna się już w połowie lat siedemdziesiątych. Zob. Kę p i ń s ki, op. cit., s. 41.

14 Warto przypomnieć zarzut, jaki przedstawicielom Nowej Fali postawił Herbert podczas IX Kłodzkiej Wiosny Poetyckiej. Mówił w dyskusji, że sferą działalności poety jest „rzeczywistość”, a nie „współczesność”, jak to uczynili poeci pokolenia '68. Zob. Poeta wobec wspótczesności. „Odra” 1972, nr 11, s. 49. - M. S ta la, Wspótczesność i rzeczywistość. (Glosy do lektury Herberta przez twórców „pokolenia '68”). „NaGłos” 1991, nr 4.

15 Skrótem K odsyłam do: R. Krynicki, Magnetyczny punkt. Wybrane wiersze i przekłady. Warszawa 1996. Liczby po skrócie oznaczają stronice. Zachowuję zapis graficzny zastosowany w tej edycji i w pozostałych, do których odnoszę się w artykule. 
ną w kulturze śródziemnomorskiej przez tradycję biblijną, kontynuowaną zaś w nowoczesnej liryce przez symbolizm i poetyki od niego nieodległe. Powie Krynicki o polszczyźnie:

nasz język ukształtował się kilka wieków później niż niemiecki. Na przykład w wierszu Celana Ty bądź jak ty zawsze istotną funkcję pełni werset $\mathrm{z}$ Księgi Izajasza cytowany przez Mistrza Eckharta w jednym z jego kazań pisanych w języku średnio-wysoko-niemieckim. Tymczasem kiedy Mistrz Eckhart pisał i wygłaszał swoje kazania, to w języku polskim nie tylko nie było jeszcze żadnych przekładów z Biblii, ale jak się zdaje, nawet „Daj, ać ja pobruszę, a ty poczywaj” nie było jeszcze zapisane ${ }^{16}$.

To swoiste przesunięcie czasu między liryką niemiecką i polską, na które wskazuje poeta, odnieść można także, jestem przekonana, do debiutanckiej fazy twórczości samego Krynickiego, świadomie zwracającego się jako tłumacz liryki niemieckojęzycznej ku tradycji w tekstach nowofalowych pomijanej. Specyficznemu cofaniu się na osi czasu, mierzonego estetykami osadzonymi na światopoglądowych wizjach, towarzyszy też zmiana w postawie poety wobec „współczesności” i „rzeczywistości”. W biografii artystycznej Krynickiego dostrzegamy wszak równoległy przełom, polegajacy na przeniesieniu akcentów $\mathrm{z}$ vita activa na vita contemplativa ${ }^{17}$. Ta ostatnia otwiera drogę ku próbom uprawiania mistyki poetyckiej.

Symbolicznym wyrazem omawianego przejścia i jego związków z tłumaczeniem liryki niemieckiej może być gra modalności, jakie uruchamiają motta do dwu retrospektywnych tomów wierszy Krynickiego - Niepodległych nicości z roku 1989 (oddanych do druku 2 lata wcześniej) oraz najobszerniejszej, jak dotychczas, summy poetyckiej z 1996 roku, zatytułowanej Magnetyczny punkt. Frazy otwierające pierwszy przegląd, zaczerpnięte $z$ tekstów Bolesława Micińskiego i Zbigniewa Herberta, podpowiadały lekturę, w której ważną funkcję pełnić winien kontekst społeczno-polityczny. Zarówno fragment Podróży do piekiet („podróż może być poszukiwaniem samego siebie, może być ucieczką przed sobą, może mieć charakter pokuty i kary” ${ }^{18}$ ), jak i cytat z wiersza Rozważania o problemie narodu („buntowałem się / ale sądzę że ten okrwawiony węzeł / powinien być ostatnim jaki / wyzwalający się / potarga"19) przedstawiają bowiem podmiot jako jednostkę uwikłaną w grę zasług i win, poddaną naciskom zewnętrznym, szukającą wolności także (choć nie tylko) w przestrzeni bycia społecznego. Wybór motta z Herberta tak wtedy odczytywano. Krynicki musiał wiedzieć, że cytując autora Przesłania Pana Cogito w czasie, gdy ten pełnił funkcję barda poezji sprzeciwu, a jego lirykę interpretowano nade wszystko jako wyraz „postawy wyprostowanej”, podpowiada czytelnikom swoisty „styl odbioru”20 także

J. Mi kołaj ew s ki, Jak obronić się przed zalewem słów. W zb.: Gdybym wiedział, s. 254. (Pierwodruk: „Gazeta Wyborcza” 2014, nr 113). Ze względu na ewentualnego czytelnika obcego warto przypomnieć, że jest to pierwsze zdanie zapisane w języku polskim, zamieszczone w Księdze Henrykowskiej, która wyszła spod pióra opata cystersów w Henrykowie, Piotra, około 1270 roku.

Wspominałam o tym w szkicu Cena milczenia. Ryszard Krynicki o uwikłaniu i wyzwoleniu poezji (w zb.: Formy zaangażowania. Pisarki i pisarze $w$ kulturze XX i XXI wieku. Red. M. B r zóstowi cz-Klajn, G. Pertka, B. Przymuszała. Poznań 2017).

18 Z. Mi cińs ki, Podróże do piekiet. Eseje. Warszawa 2011, s. 31-32.

19 Z. He rb ert, Rozważania o problemie narodu. W: Studium przedmiotu. Wyd. 2, popr. Wrocław 1995, s. 48.

20 Autorem tego terminu jest M. Głowiński (Świadectwa i style odbioru. W zb.: Problemy teorii literatury. Seria 3. Wybór H. Markiewi c z. Wrocław 1988). 
własnej liryki. Ten sposób lektury ${ }^{21}$ Niepodległych nicości uprawomocniony był dodatkowo przez fakt, iż retrospektywny tom Krynickiego nosił jeszcze ślady ingerencji cenzorskich, zaznaczonych w formie kwadratowych nawiasów $z$ wpisanym w nie numerem ustawy, na mocy której usunięto fragmenty tekstu złożonego do druku.

Zarówno tytuł, jak i motto do wydanej niespełna dekadę później summy poetyckiej, zatytułowanej Magnetyczny punkt, prowadziły uwagę czytelnika w zasadniczo odmiennym kierunku. Wybrany na motto fragment wiersza Nelly Sachs *** (Na tak krótko powierzony jest człowiek...) (*** 〈So kurz ausgeliefert ist der Mensch...)):

\author{
Dieses leidende Papier \\ schon krank vom Staub-zum Staube-Lied \\ das gesegnete Wort entführend \\ vielleicht zurück zu seinem magnetischen Punkt \\ der Gottdurchlässig ist_22
}

- eksponował wagę namysłu metafizycznego, korespondując w oczywisty sposób z pragnieniem polskiego poety, by porzucić "grzeszny język” i przemówić „świętą mową". Jego wybór wskazywał także na rolę tradycji czerpanej z niemieckojęzycznego kręgu kulturowego. W tomie Niepodległe nicości Krynicki wykorzystał bowiem tę samą metaforę $\mathrm{z}$ wiersza autorki Rozżarzonych zagadek jako tytuł zbioru przekładów z liryki niemieckiej ${ }^{23}$, zamykającego pierwszy retrospektywny tom poety. Niemal po dekadzie identyczna metafora pełnić zaczynała funkcję drogowskazu umożliwiającego poruszanie się również po twórczości Krynickiego.

Nie sposób w tak krótkim szkicu odnieść się do wszystkich tropów, jakie należałoby uwzględnić, omawiając różnego rodzaju korespondencje między liryką Krynickiego a poezją niemieckojęzyczną. Cechę charakterystyczną ewoluującego głosu autora Magnetycznego punktu stanowi narastające występowanie intertekstualnych odniesień do wierszy poetów czytanych i tłumaczonych. Sa to często pojedyncze wersy włączone przez Krynickiego do własnych wierszy na zasadzie kryptocytatu, parafrazy, czasem cytatu struktury. Można by te zabiegi nazwać - za Katarzyna Kuczyńską-Koschany - „dyskretną recepcją"24. Badaczka ukuła ten termin, chcąc opisać relację Krynickiego z Rilkem, którego utworów autor Przekreślonego początku nigdy ostatecznie nie zdecydował się tłumaczyć. Jeśli chodzi o poetów takich

21 Zob. K. My s z k ow s ki, „...jakieś Ja, które szuka swojego Ty...” W zb.: Gdybym wiedziat, s. 8384. (Pierwodruk: „Kwartalnik Artystyczny” 1998, nr 2).

22 N. S a c h s, ${ }^{* * *}$ (So kurz ausgeliefert ist der Mensch...) / *** (Na tak krótko powierzony jest człowiek...). W: Glühende Rätsel. Ausgewählte Gedichte / Rozżarzone zagadki. Wiersze wybrane. Ausgew., übertr. R. Krynicki / Wybór, przekł. R. Krynicki. Kraków 2006, s. 171.

23 Krynicki zamieścił w niej przekłady z twórczości F. Hölderlina, N. Lenaua, G. Trakla, W. Klemma, Y. Golla, N. Sachs, P. Celana, J. Bobrowskiego, R. Kunzego i S. Kirsch.

24 K. Ku c zy ń s ka - K o s c h a ny (Rilke poetów polskich. Wrocław 2004, s. 287) podkreśla milcząca obecność Rilkego w twórczości Krynickiego, konstatuje, że autor Magnetycznego punktu „dotyka najważniejszych strun tematycznych odbioru Rilkego w Polsce: pisze o róży w kontekście tanatycznym, wspomina cykl duinejski, posługuje się poetyką elegii, parafrazuje Herbsttag (Dzień dzisiejszy)". 
jak Celan czy Sachs, śmiało można mówić jednak również o jawnych odniesieniach do ich tekstów.

Zmuszona do dokonania wyboru, skoncentruję się tylko na dwu wymiarach interesujących mnie poetologicznych interferencji: na „miejscach wspólnych” 25 poetyki, rozumianej tu przede wszystkim jako teleologicznie uzasadniony typ wyrazu, a także na łączności związanej z ideowymi poszukiwaniami, których zbieżność potwierdzać może (bądź podważać) pokrewieństwo tematów, pragnień i stawianych pytań.

W jednym $z$ wywiadów autor Magnetycznego punktu odnosił się do obu wymienionych kwestii. Odrzucając zrazu teorię dotyczaca prostych symetrii w sposobie konstruowania frazy, chwile później podkreślał wpływ tłumaczonych twórców (tu konkretnie Celana) na jego własne rozumienie pojęć. Kierunek myślenia miałby być zatem ważniejszy od chwytu poetyckiego? Albo, dokładniej, idiom stanowiłby rodzaj śladu po poszukiwaniach podejmowanych w sferze idei? Zapewne! Krynicki mówił:

Mimo że przekładam ich [tj. Celana i Sachs] wiersze do dziś, nie wydaje mi sie jednak, by miały one bezpośredni wpływ na mój sposób pisania. Natomiast na mnie piszącego wiersze - tak. Teraz, po wielu latach czytania Celana, nie przywołuję już w poezji słowa „nicość” tak pochopnie, jak kiedyś26.

Faktycznie, poeta nie korzysta z tego wyrazu - moglibyśmy dopowiedzieć - bo dzięki głębokiemu poznaniu utworów autora Fugi śmierci (Todesfuge, 1948) pojęcie nicości, jak wiele innych, obrosło znaczeniami dotąd w języku Krynickiego ze słowem tym nie związanymi. $Z$ biegiem czasu coraz klarowniej widać wagę, jaką dla myślenia Krynickiego wierszem miała lektura Celana. Kuczyńska-Koschany przedstawiła w świetnej interpretacji kolejnych wersji Trzech fragmentów z roku 1989, jak w utworze $z$ tematem rilkeańskim Krynicki zaczyna mówić Celanem. Jest jeszcze bardziej oszczędny, redukuje frazę, buduje przestrzeń znaczącego milczenia. Usuwa nawet ślady (występujące w pierwszej wersji wiersza), które wskazują w formie kryptocytatu na poetyckiego promotora czynionych redukcji:

$$
\begin{aligned}
& \text { świt, koloru Sekwany } \\
& \text { koloru octu i żółci, } \\
& \text { niesie różę, } \\
& \text { Niczyja } \\
& \text {................... } \\
& \text { pod tyloma } \\
& \text { spalonymi } \\
& \text { powiekami }{ }^{27}
\end{aligned}
$$$$
\text { koloru octu i żółci, }
$$$$
\text { świt, koloru Sekwany, }
$$$$
\text { koloru piołunu i żółci }{ }^{28}
$$

Właśnie w odkryciu roli milczenia, które u Celana stanowi wynik traumy, upatrywałabym największego wpływu tego autora na jezzyk poetycki późnego Krynic-

Miejsca wspólne. Szkice o komunikacji literackiej i artystycznej. Red. E. Ba l c e r z a n, S. Wy sł ou c h. Warszawa 1985.

26 Kępińs ki, op. cit., s. 42.

R. Kry nicki, Trzy fragmenty z roku 1989. „W Drodze” 1992, nr 2.

W Magnetycznym punkcie przedrukowana zostaje ta druga, oszczędna wersja, z 1996 roku - nieprzypadkowo przecież (K 292). 
kiego $^{29}$. On sam wskaże w tym względzie na przykład, jaki czerpał od Herberta ${ }^{30}$. W zakresie idiomu to jednak „punktualistyczna” 31 „poetyka ekspiracji”32 Celana zdaje się wytyczać - wbrew temu, co mówi Krynicki o braku wpływu tłumaczonych poetów na jego własny język w cytowanym wywiadzie przeprowadzonym przez Katarzynę Janowską i Piotra Mucharskiego - kierunek postępującej redukcji słowa, rwącego się toku wypowiedzi, których skutkiem staje się wielość traumatycznych (a może w przypadku Krynickiego raczej metafizycznych?) znaczeń. Liczne przykłady narastania tych cech w jego poetyckim idiomie napotkamy w Wierszach igłosach (1985), w tomie Kamień, szron (2005) czy w Przekreślonym początku (2013). Alvin H. Rosenfeld stwierdza:

Czytając późniejszą twórczość Celana, coraz częściej odnajdujemy wiersze w pewien sposób okrojone i eliptyczne, krótkie, mieszczące się na jednej stronie, napisane językiem niezmiernie osobistym i nawet hermetycznym. Słowa rozpadają się na oddzielone sylaby, składnia ulega zaburzeniu, oddech staje się coraz krótszy i cięższy. Barwy, nigdy nie obfite w utworach tego poety, wypłowiały do bieli i szarości, jak gdyby coś pod powiekami uległo uszkodzeniu. Dźwięki rozbrzmiewają coraz słabszym echem i zdają się pochodzić $\mathrm{z}$ jakiś odległych miejsc ${ }^{33}$.

Ten wnikliwy opis Rosenfelda dotyczący języka Celana z późniejszego okresu jego twórczości moglibyśmy bez obawy wykorzystać dla deskrypcji znamiennych cech liryki dojrzałych wierszy Krynickiego. W ostatnich tomach polskiego poety odnajdziemy wiele podobnych - „celanowskich” właśnie - wierszy. Mowa o dwu-, trzy-, czterowersowych utworach, często pozbawionych tytułu, niekiedy z naruszoną spójnością składni lub „atonalnym” tokiem wypowiedzi, którego płynność zostaje osłabiona wskutek posługiwania się wydłużoną pauzą, słyszalną w szeregach urwanych pytań i niedomkniętych, ,jąkających się"34 fraz. Te ostatnie nierzadko

Badacze wielokrotnie opisywali milczenie jako jedną z najważniejszych dystynktywnych cech poetyki Krynickiego. Nigdy wszakże, o ile mi wiadomo, nie czynili tego w ramach porównania z liryką Celana.

30 Zob. Janowska, Mucharski, op. cit., s. 99.

31 Termin S. B a lb u s a (Moje domysty ojednym wierszu Paula Celana. W zb.: Literatura i literackość 〈według〉 Edwarda Balcerzana. Konteksty „niewszystkie”. Red. J. G rą dzi el-Wój cik, T. Mizerkiewicz. Poznań 2017). Badacz wyprowadza go, odkrywając podobieństwo między tokiem wypowiedzi autora Fugi śmierci a atonalną, punktualistyczną muzyką A. Weberna, ulubionego kompozytora Celana. Warto tu może przytoczyć bardzo trafne uwagi B albu s a (ibidem, s. 225) dotyczące związków między punktualistycznością Celanowskiej frazy a rolą, jaka w tej poezji przydana zostaje milczeniu: „Jego [tj. autora Przełomu oddechu] wiersze składają się nie tylko ze słów, ale $\mathrm{w}$ równej, o ile nie większej mierze $\mathrm{z}$ milczenia, $\mathrm{z}$ ciszy, $\mathrm{w}$ której precyzyjnie wyważone słowa rodzą znaczenia, jakich same bezpośrednio nie potrafią lub bezpośrednio nie chcą wyrazić. Ciszy wokół wierszy, w białej płaszczyźnie kart, i wewnątrz, między słowami, między wierszami, w interliniach i podwójnych interliniach. U Celana interlinie też są zapisane - niewidocznym pismem znaczącego milczenia. [...] Tak jak u Weberna, poprzez atonalne szeregi dźwięków daje się niemal fizycznie usłyszeć ciszę, nieskończone odmiany cisz. Dźwięki czynią ją słyszalną, jakby temu zwłaszcza miały służyć”.

32 Termin A. H. Ro s e nfeld a (Poetyka ekspiracji. W: Podwójna śmierć. Rozważania o literaturze Holocaustu. Przeł. B. Kraw c ow ic z. Warszawa 2003). Ibidem, s. 134.

34 A. H. Ro s e n feld (Prawując się z milczacym Bogiem. W: Podwójna śmierć, s. 152) pisał o „kompulsywnym jąkaniu”, które doprowadza wiersz do granicy bezładnego bełkotu, „niepokojąco blisko Hölderlinowskiego bezradnego "Palaksz, palaksz". 
wymagają od czytelnika rozwiązania zagadki pojedynczych słów, ba - głosek, pojawiających się w wierszu. Pozwalają także słyszeć ciszę, która - jak pisał Stanisław Balbus o Celanie - brzmi w naszych uszach dzięki skapo wypowiadanym dźwiękom ${ }^{35}$.

Wszystkie przywołane poniżej wiersze przypominaja język poetycki autora Zagrody czasu, od którego Krynicki czerpie niejednokrotnie również na zasadzie kryptocytatu, parafrazy, repetycji obrazu:

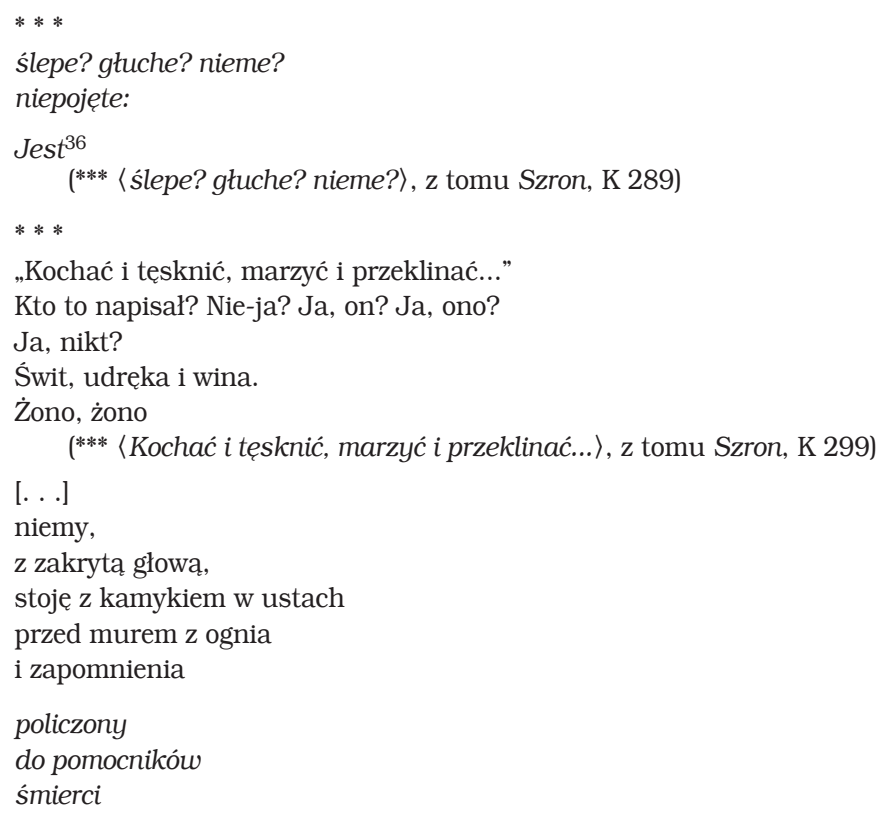

(Fragmenty z roku 1989, z tomu Przekreślony poczatek, K 290)

W ostatnim z przywołanych przykładów trudno przeoczyć obraz znany z wiersza Celana zatytułowanego Syberyjsko (Sibirisch) opublikowanego w tomie Róża niczyja (Die Niemandsrose, 1963). Podmiot wypowiadajacy wiersz, zwracając się do martwej kobiety, ma w gardle kamień, który dławi i oddech, i możliwość mowy. Skontrastowany z białym kamykiem w niegdyś żywych ustach kobiety, których wspomnienie wywołane zostało przez widok kwitnacego syberyjskiego dzwonecz$\mathrm{ka}^{37}$, symbolizuje słowna niemoc poety wobec dramatu egzystencji:

B alb u s, op. cit., s. 225.

Wcześniejsza wersja tego samego wiersza była dłuższa o jedno, padające w klauzuli, słowo: „Boli”. Kursywa nowszej wersji zdradza - jak to się często zdarza w późnej poezji Krynickiego - że mamy do czynienia z zapożyczeniem, z przejęciem cudzego jako własne. To zresztą zabieg spotykany także u Celana.

W jezzyku niemieckim słowo „Schelle” ma jednak również drugie, bardziej złowrogie znaczenie. Użyte w żeńskiej formie, rozumiane jest jako obręcz, konotującą sensy zniewolenia, usidlenia, ograniczenia. Krynicki nieprzypadkowo wybiera formę masculinum (der Schelle - dzwonek). Postępuje tak zapewne przez pamięć o roli antropomorfizowanych obrazów przyrody w liryce Celana, wpisujących się w „ogólny antropomorficzno-naturalistyczny "kod" poetyckiej wyobraźni symbolicznej” (B a lb u s, op. cit., s. 237). W wierszu Syberyjsko, podobnie jak w wielu innych utworach, mamy do czynienia $z$,antropomorfizacją przyrody na gruncie empatycznej wspólnoty "instynktu śmierci", gdzie lęk splata się z fascynacją, groza przenika urzeczenie” (ibidem). 
Kleine, im Eiswind

liegengebliebene

Schelle

mit deinem

Weissen Kiesel im Mund:

Auch mir

steht der tausendjahrfarbene

Stein in der Kehle, der Herzstein,

auch ich

setze Grünspan an

an der Lippe.
Mały, pozostały

w lodowatym wietrze

dzwoneczek

$z$ twoim

białym kamykiem w ustach:

mnie też

stoi w gardle kamień

o barwach tysiącleci, kamień serca,

mnie też

osadza się śniedź

na wardze ${ }^{38}$.

Krynicki w cytowanym wcześniej trzecim Fragmencie z roku 1989 powtarza Celanowski obraz kamienia zawadzającego w ustach. W utworze tym kamyk symbolizuje niemotę człowieka postawionego wobec gehenny ofiar, a także zapomnienia pytanego o winę, zapomnienia, które $\mathrm{z}$ ocalonych czyni milczących „pomocników śmierci”.

Zarówno u Celana, jak i u Krynickiego urywany, często eliptyczny, czasem zaś tylko przedstawiony jako eliptyczny, tok wypowiedzi buduje „złożony układ znaczeniowych napięć, prowadzacych bezpośrednio do wyłonienia się w przestrzeni przemilczeń wiersza wielkiej metafory kulturowej, o niedomkniętych i rozrastających się w tej przestrzeni sensach"39. Czy znaczenia te sa jednak u obu poetów bliskie? Czy posługując się formą podobna do struktury wiersza Celanowskiego, Krynicki dąży do wyrażenia symetrycznych przesłań? Czy - powiedzmy to prościej - jego liryka przemawiająca tyleż głosem, co milczeniem znaczona jest dramatem pokrewnym autorowi Róży niczyjej? Daleka byłabym od stawiania tego typu tez. Przeciwnie, sadzę raczej, że poszukiwania Krynickiego zmierzają w innym kierunku. Jego celem w mniejszym stopniu jest wyrażenie traumy, w większym - refleksja metafizyczna (co również u Celana nie zawsze się wyklucza). Najlepiej o owym znaczącym przesunięciu akcentów przekonuje wiersz stuk-puk, zamykający Magnetyczny punkt, opublikowany zaś powtórnie w tomie Przekreślony początek (2013). Nb. ta jak dotąd ostatnia książka poetycka Krynickiego uświadamia, że opisywane wcześniej przejście od zaangażowanego głosu artysty zwiąanego z Nową Falą do liryki namysłu metafizycznego łączy się nieodmiennie z pokrewną ufnością w pozytywny horyzont dążeń twórczych. Dojrzała poezja Krynickiego nie rodzi się jak liryka Celana „w cieniu nihilizmu”, ale przeciwnie - łączy się z pragnieniem pokonania nicości. Odpowiedzią na bolesne doświadczenie i dramatyczne rozpoznanie jest tu niemal zawsze akt zwrócenia się ku temu, co „Jest”, co „drży na końcu języka” (Unoszone wiatrem, z tomu Przekreślony początek, K 171), co pozwala raczej „iść”, niż „błądzić” ${ }^{40}$, by odwołać się do znamiennych kod kilku utworów zamieszczonych w tomie. übertr. R. Krynicki / Wybór, przekł. R. Krynicki. Todesfuge übertragen von S. J. Lec / Fuga śmierci w przekładzie S. J. Le c a. Kraków 2013, s. 182-183.

40 R. Krynicki, *** (nagi, obudzitem się nagle $w$ kolejce po chleb...). W: Przekreślony poczatek. Dwadzieścia dwa wiersze z lat 1965-2010. Wrocław 2013, s. 5. 
Niepodlegli nicości, podajmy dalej

niebotyczne pismo obłoków,

podawajmy je z ust do ust. [Podajcie dalej, z tomu Przekreślony początek, K 159]

- wzywa poeta, żeby parę stronic dalej skrócić epigramatyczny wiersz *** (Ślepe? Głuche? Nieme?...) (K 263) o traumatyczne „boli”, domykając ciagg urywanych pytań w nowej wersji utworu jedynie afirmatywnym „Jest” (*** 〈ślepe? głuche? nieme?...〉). Można by rzec: autor Przekreślonego początku zachowuje optymistyczną wiarę, która nowofalowcom pozwalała ufać w pozytywny efekt interwencyjnych działań w przestrzeni życia społeczno-politycznego. Inaczej ją jednak wykorzystuje. W milknącej poezji Krynickiego, zbliżającej się coraz wyraźniej ku mistyce, ufność w sens rodzi konieczność tworzenia wierszy, które Czesław Miłosz nazwałby „lekturami budującymi" ${ }^{41}$.

To swoiście afirmatywne wobec istnienia metafizyczne wychylenie potwierdza przywołany wiersz stuk-puk ${ }^{42}$. Krynicki posługuje się w tym utworze formą, która przypominać może nie tylko „poetykę ekspiracji” Celana, ale także lingwistyczny idiom Mirona Białoszewskiego. (Inicjały polskiego poety nieprzypadkowo odnajdujemy w dedykacji zbliżonej do didaskaliów ${ }^{43}$.) Autor Magnetycznego punktu bawi się słowem; zawieszając wydech, wypowiada poprzez język arbitralnych pauz projekt odnajdywania „cości” w tym, co jest jej pojęciowym antonimem:

Cz. Miło s z, Ziemia Ulro. Przedm. J. Sa dzik. Kraków 1994, s. 158.

Wiersz ten był wielokrotnie interpretowany. Zob. W. Kalis zewski, Milczaca wolność. "Więź” 1997, nr 5. - P. Mi c hał ow s ki, Pod żelazna kurtyna obłoków. O poezji Ryszarda Krynickiego. „Pogranicza” 1997, nr 3. - L. Sz a r u ga, Czytam Krynickiego. „Śląsk” 1997, nr 1. - I. M i s i a k - B r o d a, Ciche gniazda os. „Res Publica Nowa” 1999, nr 7/8. - P. Kr u piń s ki, Róża nicości. O „Magnetycznym punkcie” Ryszarda Krynickiego. „Krasnogruda” 2000, nr 10. - A. Ś w i e ś c i a k, Przemiany poetyki Ryszarda Krynickiego. Kraków 2004.

Krytycy zwracali uwage na ten macierzysty kontekst wielokrotnie, odczytując motto jako odautorską „sugestię, że cały wiersz został poecie podyktowany” przez M. Białoszewskiego w marzeniu sennym, które, co prawda, sugerować by mogło także „przestrzeń objawienia, oświecenia”. Twórca tej tezy - Cieśla k-Sok ołowski (op. cit., s. 331-339) - w trzech ostatnich wersach stuk-puk odnajdywał nawet (co mnie wydaje się wątpliwe) kryptocytat z Rozkurzu Białoszewskiego. W rozbudowanej, wielowatkowej interpretacji wiersza badacz zestawiał kilka jego alternatywnych odczytań, ostatecznie stawiając tezę, że stuk-puk poświadcza powrót Krynickiego do poetyki konceptu jako chwytu otwierającego grę lingwistyczną na refleksję metafizyczną, pozbawioną jednak pewności orzekania i prostej aklamacji „coś/ci”. Miejsce afirmacji zajmowałaby tu troska o nietrwałe „Jest”. Cieślak-Sokołowski przypominał słusznie, iż R. Kry n i c ki w szkicu Czy istnieje już poezja lingwistyczna? („Poezja” 1971, nr 12) proponował, by w grze słownej ujrzeć narzędzie refleksji metafizycznej. Warto te słowa przywołać. Kry n i cki (ibidem, s. 48) pisał, polemizując ze stawianym Nowej Fali zarzutem uprawiania pustych gier słownych: „Moim zdaniem, postawa ludyczna może być także odmianą (czy: namiastką, wstępem i reliktem) postawy metafizycznej, i w poezji swoje najdoskonalsze wcielenie znalazła w barokowym konceptualizmie, nie zmanierowanym jeszcze przez manierystyczne wynaturzenie. Gra jest bowiem (a przynajmniej być może) małą metaforą transcendencji”. Stuk-puk stanowiłby w zaproponowanej przez Cieślaka-Sokołowskiego optyce powrót do lingwizmu, który nie wyklucza się, ale wręcz przeciwnie - splata się z namysłem metafizycznym. Rozpoznania o roli konceptu w późnej twórczości Krynickiego zbiegają się także z obserwacjami czynionymi przez B. Śn i e c i k ow s ką (Haiku po polsku. Genologia w perspektywie transkulturowej. Toruń 2016, s. 191-192, 340-488), która przygląda się miniaturom poetyckim Krynickiego z pytaniem o ich ewentualną zbieżność z haiku i „mironū” Białoszewskiego. 
(przez sen,

do M. B.?)

$$
\begin{aligned}
& \text { nic } \\
& \begin{array}{l}
\text { ości } \\
\text { nie ma } \\
\text { ale coś } \\
\multicolumn{1}{c}{c} \\
\text { ma } \\
\text { (być }^{44}
\end{array}
\end{aligned}
$$

Alina Świeściak, analizując (jak dotychczas najobszerniej) strategie milczenia w liryce Krynickiego, widziała w tym wierszu przykład kryzysu języka. Pisała, że stuk-puk ,zdaje się otwierać [...] dwojaką perspektywę: powtórzenia ([...] grę cytaminiresztkami) lub milczenia jako znaku wyczerpania" ${ }^{25}$. Sądzę, iż to mylne rozpoznanie. Lingwistyczna zabawa słowem, która sprawiać może, co prawda, wrażenie aktu jego degradacji, dekompozycji, rozpadu, służy w tym wierszu przecież twierdzeniu, że nawet nicość zawiera w sobie energię „istoczenia się” znaczeń, jak powiedziałby Heidegger. Argumentów na rzecz takiej lektury dałoby się przytoczyć więcej niż kilka. Po pierwsze, przyrostek „ości”, wyodrębniony punktualistyczną pauzą ze słowa „nicość”, konotuje pojęcie tego, co w organizmie - czy to ludzkim, czy zwierzęcym - najbardziej trwałe (jak ość lub kość). Po drugie, wyraźna oś symetrii strukturalnej, jaką wyznacza w omawianym utworze wers czwarty (,ale coś”), stanowi równocześnie oś antynomii między negowaną nicością a pożądanym byciem. O ile w pierwszych trzech wersach poeta zdaje się sens tej pierwszej podważać („nic / ości / nie ma"), o tyle w trzech ostatnich zwraca się wyraźnie ku byciu, które wyłonić się może nawet $z$ najmniejszego skrawka języka, dźwięku, pojedynczej głoski, jeśli tylko usłyszymy w okalających je pauzach potencje esse (,ć / ma / 〈być)”). Nawias, w którym umieszcza Krynicki ostatnie słowo, może wprawdzie zostać odebrany jako znak niepewności. Nawet wówczas nie przekreśla to jednak (przeciwnie - prędzej wydobywa) siły pragnienia, jakie wyraża poeta w interpretowanym wierszu. Stuk-puk czytać wolno, jak sądze, jako parafrazę sławnego pytania Gottfrieda Wilhelma Leibniza: „dlaczego raczej istnieje coś, zamiast by raczej nic nie istniało, zważywszy, że nic jest łatwiejsze niż coś?"46.

Autor Magnetycznego punktu - podobnie do niemieckiego filozofa - w swojej późnej liryce stawia „zasadę racji dostatecznej” 47 jako kluczową i pierwotną wobec przywołanej kwestii. Leibnizowskie pytanie należałoby bowiem uznać za sensowne jedynie wówczas, gdy przyjmiemy? (odkryjemy?), że istnieje jakiś powód, który

\section{Kraków 2005, s. 65.}

Na temat koncepcji bytu jako pojęcia, które zawiera w sobie coś pozytywnego, G. W. Leibniz (Wyznanie wiary filozofa. - Rozprawa metafizyczna. - Monadologia. - Zasady natury i łaski oraz inne pisma filozoficzne. Przeł. S. Ci chowicz, J. Domański, H. Krzeczkowski, H. Moense. Oprac., wstęp S. Ciechowicz. Warszawa 1969, s. 233, 234, 245, 258) pisał wielokrotnie. 
pozwoli potraktować „coś” jako bardziej oczywiste niż „nic”. W filozofii autora Monadologii ową „rację dostateczną” stanowił - jak pamiętamy - Bóg. A u Krynickiego? Cóż by nią mogło być? Co podpowiadają mu w tym względzie poeci niemieckojęzyczni, których tłumaczonymi tekstami polski twórca przemawia, w pewnej mierze na prawach własnego głosu. Mam powody sądzić, że w myśleniu o „racji dostatecznej” Krynicki bliższy jest raczej Sachs niż Celanowi. Gdyż podziela jej nadzieję chroniona z trudem - pełne rozpaczy pragnienie, by „obolały papier / chory już od naszych z-prochu-w-proch-pieśni” wskazywał mimo wszystko „błogosławione słowo" (K 282).

Pamiętamy wspaniały wiersz Celana Zurych, Zum Storchen (Zürich, Zum Storchen), włączony do tomu Róża niczyja ${ }^{48}$. Twórca „zapisuje” w nim dialog z Nelly Sachs, której ten wiersz jest dedykowany. Poeci rozmawiaja „o żydowskości i o Bogu [...] w kontekście swoich doświadczeń" ${ }^{49}$, wypowiadają się z głębin rany Holocaustu. Dialog toczy się naprzeciw katedry, „am Tag einer Himmelfahrt”50, czyli w dniu celebrowanym przez chrześcijan jako pamiątka Wniebowstapienia, znak triumfu nad śmiercią. W wierszu Celana Wniebowstapienie jest wszak (co potwierdza forma rodzajnika w słowie niemieckim: einer Himmelfahrt) nieokreślone, pozbawione wzniosłości, jest jednym $z$ wielu. Rosenfeld słusznie zwracał uwagę, że autor Fugi śmierci nawiązywał tu raczej do pamiętnego obrazu z wiersza Sachs, w którym Wniebowstapienie przedstawione zostało jako „wniebowstapienie "ciała Izraela, rozwianego w dym" wznoszącego się ku górze przez "kominy / w siedzibach śmierci stworzonych genialnie [...]" "51. Celan mówi w utworze Zurych, Zum Storchen „przeciwko Bogu”, nie nazywa Go własnym. Ale zwracając się do Sachs, dwukrotnie używa sformułowania „twój Bóg”, jakby w chęci podkreślenia swojego dystansu:

$\begin{array}{ll}\text { Von deinem Gott war die Rede, ich sprach } & \text { Mowa była o twoim Bogu, ja mówiłem } \\ \text { gegen ihn, ich } & \text { przeciwko niemu, } \\ \text { liess das Herz, das ich hatte } & \text { sercu, jakie miałem, kazałem } \\ \text { hoffen: } & \text { wierzyć } \\ \text { auf } & \text { w jego } \\ \text { sein höchstens, umröcheltes, sein } & \text { najwyższe, spowite rzężenie, jego } \\ \text { haderndes Wort - } & \text { kłótliwe słowo - } \\ \text { Dein Aug sah mir zu, sah hinweg, } & \text { Twoje oczy patrzyły na mnie, patrzyły poza mnie } \\ \text { dein Mund } & \text { twoje usta } \\ \text { sprach sich dem Aug zu, ich hörte: } & \text { dopowiadały się do oczu, słyszałem: } \\ \text { Wir } & \text { My } \\ \text { Wissen ja nicht, weisst du, } & \text { przecież nie wiemy, wiesz } \\ \text { wir } & \text { my } \\ \text { wissen ja nicht, } & \text { przecież nie wiemy, } \\ \text { was } & \text { co jest } \\ \text { gilt. } & \text { ważne } \\ \end{array}$

Wiersz ten i jego przekłady Krynickiego i J. Ekiera bardzo ciekawie interpretowała Rajews ka (op. cit., s. 114 n.).

49 Rosenfeld, Poetyka ekspiracji, s. 149.

50 P. C e la n, Zürich, Zum Storchen / Zurych, Zum Storchen. W: Psalm und andere Gedichte / Psalm $i$ inne wiersze, s. 161.

51 Ros enfeld, Poetyka ekspiracji, s. 148-149.

52 C el a n, Zürich, Zum Storchen / Zurych, Zum Storchen, s. 160-161. 
Celan mówi o Bogu $z$ wyrzutem, mówi „przeciwko niemu”. Sachs odpowiada mu zrazu milczącym wzrokiem utkwionym gdzieś w dali. Patrzy mimo jego gniewu, by w końcu $z$ wyraźnym trudem wycedzić słowa o niemożliwości potwierdzenia, o braku wiedzy, o niepewności, czy coś jeszcze ocalało i zachowało dawną wagę. W wypowiedzi poetki usłyszeć można jednak także nadzieję, że są sprawy liczące się nadal. Tak przynajmniej zdaje się ją rozumieć Krynicki, który nieprzypadkowo przecież myśl o „błogosławionym słowie”, a nie „słowie kłótliwym”, „spowitym rzężeniem", jak pisał Celan, wybiera na motto własnej summy poetyckiej. Prawdopodobnie polski poeta czyni tak przez pamięć o późnych wierszach Sachs, o jej tomie Śmierć jeszcze cieszy się życiem (Noch feiert Tod das Leben, 1961), o którym Rosenfeld pisał:

„w ostatnim oddechu życia” [...], na chwilę zanim westchnienie duszy umknęło w nicość, Sachs [...] być może rozwiązała najbardziej tajemniczą $\mathrm{z}$ zagadek - w jaki sposób język, wyczerpując się, wciąż może zabrzmieć: w jaki sposób „śmierć wciąż świętuje życie”. „Poczekaj - obiecuje - Poczekaj aż oddech zamrze / nadal będzie dla ciebie śpiewał" [...] $]^{53}$.

Rosenfeld nie bez powodu przypominał właśnie te słowa Nelly Sachs, wypowiadane nie wbrew, ale mimo doświadczonej traumy. Sięgając po jedną z ksiąg Zoharrozdział Tajemnice Stworzenia - tłumaczona przez Gershoma Scholema, poetka szukała języka, który mimo gniewu i rany pozwalałby jej udręczonemu ciału złapać oddech. „W Zoharze [...] "spotyka się mistyka całego świata" - przypominał Krynicki myśl niemieckojęzycznej Żydówki ${ }^{54}$. Sam własne wyznanie o pragnieniu odnalezienia „świętej mowy”, która zastapić miałaby „grzeszny język”, nieprzypadkowo zestawiał w Magnetycznym punkcie z epigramatycznym wierszem-powtórzeniem *** (Z Mistrza Eckharta czy księgi Zohar?), złożonym z dwóch słów oddzielonych przecinkiem: „nic, Bóg” (K 273). Poszukiwania autorki Drogi w bezpyt niewatpliwie miały wpływ na ten wybór.

Krynicki wspólnie z Nelly Sachs odpowiedzi na pytanie o „rację dostateczną” poszukiwał w pismach mistyków. Trzeba dodać, że w punkcie wyjścia do tych starań był w sytuacji nieporównanie łatwiejszej niż Sachs i Celan - nie doświadczył przecież bezbrzeżnej samotności i opuszczenia, nie doznał poczucia dominującej nieobecności Boga, opisywanej przez autora Psalmu. Prawdopodobnie dlatego, tłumacząc wiersz Sachs, ten sam, który uczyni niewiele później drogowskazem umożliwiającym poruszanie się po jego twórczości, Krynicki pominął jedno - zdawałoby się - mało znaczące wyrażenie. $Z$ przedostatniego wersu tego przekładanego bardzo wiernie (nieomal filologicznie) tekstu moca decyzji tłumacza zniknęło słówko „zurück [z powrotem]”. Czyżby Krynicki podpowiadał w taki sposób, że jego własna droga do „magnetycznego punktu” jest szlakiem skierowanym w przyszłość, nie zaś - jak w przypadku Sachs i Celana - ścieżką prowadząca w najlepszym razie w kierunku tego, co zostało zabrane, zrabowane, co uszło z dymem pieców?! Owa ingerencja twórcza we frazę Sachs stanowiłaby wówczas subtelny znak zasadniczej różnicy dzielącej doświadczenia niemieckojęzycznych poetów żydowskich i ich pol- 
skiego tłumacza, a także, może przede wszystkim, pełny szacunku ukłon w stronę ich cierpienia:

So kurz ausgeliefert ist der Mensch

Wer kann da über Liebe sprechen

Das Meer hat längere Worte

auch die kristallgefächerte Erde

mit weissagendem Wuchs

Dieses leidende Papier

schon krank vom Staub-zum-Staube-Lied

das gesegnete Wort entführend

viellecht zurück zu seinem magnetischen Punkt

der Gottdurchlässig ist -
Na tak krótko powierzony jest człowiek

Któż może tu mówić o miłości

Dłuższe słowa zna morze

i ziemia wachlarz kryształów

$\mathrm{z}$ proroczym wzrastaniem

Ten obolały papier

chory już od naszych z prochu w proch pieśni

może naprowadzi błogosławione słowo

na magnetyczny punkt

przez który przenika Bóg _ 55

„W poezji Krynickiego, jego własnej i przez niego tłumaczonej” - pisała trafnie Ewa Rajewska, omawiając „ocierające się o siebie metafizyki” autora Przekreślonego początku i podziwianych niemieckojęzycznych poetów: „nadzieja na otrzymanie odpowiedzi od ty [...] wydaje się zwiększać" 56 . Oznacza to, że twórca związany debiutem z pokoleniem Nowej Fali - w dużej mierze dzięki lekturze Celana, Sachs, Rilkego, Enzensbergera - odnalazł drogę ku słowu, odpowiadającą najgłębszemu pragnieniu człowieka złaknionego „istoczących się” sensów. Ciężar owego odkrycia docenić może tylko ten, kto już napotkał na kartach tomów poetyckich „wiersze, przez które zdaje się przenikać Bóg. A jeżeli ktoś boi się tego słowa [...] - wiersze, przez które przenika Niewypowiedziane, Niepojęte, przez które przenika Jest” 57.

\author{
Abstract \\ AGATA STANKOWSKA Adam Mickiewicz University, Poznań \\ ORCID: 0000-0002-9721-2493
}

\title{
ON THE WAY TO "MAGNETIC POINT" RYSZARD KRYNICKI'S POETIC DIALOGUES WITH PAUL CELAN AND NELLY SACHS
}

Spatial metaphor of "magnetic point" is a key formula of poetry writing in Ryszard Krynicki's mature creativity. The author, who in the moment of his debut was connected with Nowa Fala (New Wave), with time more often and forcibly started speaking about the need of abandoning (or at least limiting) the social functions of poetry for taking part in the mystery of "sacred speech." He strives for achieving such an act of creation and silence which would be transparent to what is absolute. The metaphor of "magnetic point" gives name to the poet's growing desire to cross the borders of "the present day" and even further-the borders of perception-and to inhabit the core of sense. What supports it is a clear return to the tradition of symbolism and interest in neo-classicist dictions. Krynicki finds his guides on this way in Polish lyric poetry. Special role here is played by Zbigniew Herbert, and not less important are German lyric poets whom Krynicki translated: Paul Celan, Georg Trakl, Reiner Kunze, Friedrich Hölderlin, and Nelly Sachs. It is from the poem which starts with the incipit *** (So kurz ausgeliefert ist der Mensch...) (*** (Man suffers such short shrift...)) that Krynicki adopted the metaphor of "magnetic point." The article offers an attempt at describing some dialogues and correspondence between Krynicki's quests and German lyric poetry, especially that by Sachs and Celan.

S a ch s, op. cit., s. 171.

Rajewska, op. cit., s. 117.

E. Sonne nberg, R. Lièv re, Ćwiczenie $w$ cierpliwości. W zb.: Gdybym wiedziat, s. 130. (Pierwodruk: „Studium” 2005, nr 4/5). 